\title{
The Application of Computer Technology in Illustrations
}

\author{
Li Quntao \\ Jiangxi College Of Foreign Studies
}

\begin{abstract}
The 21st century is a era when art and technology fusion. The combination of every aspect of science and art is more and more beyond people's imagination. The widespread popularization and application in the field of computer technology in art promotes the development and prosperity of art and also makes a new art form which is a combination of the computer and illustration art--- digital illustration.
\end{abstract}

KeyWords-Computer technology; Illustrations; Digital illustrations

\section{INTRODUCTION}

In foreign countries, enjoying the illustrations in the society has become a habit. On the one hand, a large number of independent illustrations products are on sale in the market, on the other hand, illustrations are widely applied in printed ads, posters, covers and the contents of other designs. It is well known that the commercial animation is one of the important industries of Japan. Cartoon, which is an important branch of illustration art, was all made by hand before CG technology was into the field. And today's younger generation more and more tends to use a computer to create. In South Korea, as the game industry in recent years is rising for the second pillar industry of national economy, illustrations, especially the game characters designed by digital illustration, won the larger market space due to the popularity of South Korean games in China.

Entering 2000, the fast popularization of computers in our country impetus to the development of digital illustration art. Constantly update and development of computer hardware and software also injects new blood to digital illustration art. Due to the more varied forms and styles compared to the traditional illustration, digital illustration does not only attract the attention of the public, but also changes the public's aesthetic tendency. But the subsequent "copy" orientation, paying too much attention on technology and other negative influence more or less diffuse in the design of digital illustration. This paper carry out the discussion under the background of the rapid development of technology brings unprecedented change to modern illustration art.

\section{THE CONCEPT OF COMPUTERS}

A computer is made up of hardware and software. "Hardware" refers to the physical device composed of various kinds of electronic components and circuit. The so-called "software" refers to the steps and related data collectively which are regulated in advance for the information process of computers. Software is usually interpreted as a computer program and tends to record on the disk or $\mathrm{CD}$, which can increase or decrease and modify at any time, so it is called "soft equipment" or "software". Hardware and software are complementary to each other. If computers only have " hardware" without "software" which gives commands, computers cannot work; if computers only have "software" without

"hardware" , they cannot work, either. Only when hardware and software constitute a complete system, can computers give full play to the power.

Nowadays, computer plays an indispensable role in many areas of people's life, such as work, study and entertainment. For art design field, its influence is unprecedented. It does not only update the design idea, but also standardize design and production. So the involvement the computer in the history of human design plays an epoch-making role.

\section{THE APPLICATION OF DIGITAL ILLUSTRATION IN ADVERTISING INDUSTRY}

The most successful use of digital illustration in advertising industry is in poster design. The content of the 
advertisement poster mostly uses the image of the product or the object, which expresses through photography or realistic illustrations. Such digital illustration can be used in the poster design after the process of a variety of art ways, such as the segmentation and exaggeration of the comparison of the color and the structure, which can form a better design element. The variety of artistic rendering and filter effects provided by computer graphic design software can easily realize the art processing of graphics and images. As shown in Fig .1.this is a production process of a product advertising poster. According to the purpose, the designer impersonates the product and gives the interesting scene and plot.

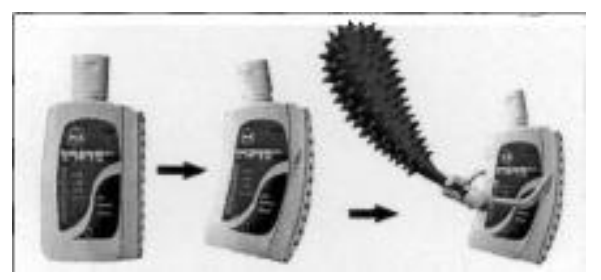

Figure 1. The design process of an advertising poster element

Designer shoots the product and put the photo into the computer. Then open the photo in photoshop software, and uses a simple distortion filter command to get the second picture, then use the airbrush tool to draw "hand" and mace. At last, according to requirement, add text and background effect Then the photo becomes a successful poster. It cannot be so simple if the traditional way of drawing is used.

\section{THE APPLICATION OF DIGITAL ILLUSTRATION IN THE CARTOON INDUSTRY}

Speaking of cartoon, especially Japanese comic books are quite popular among the boys and girls, like "Dragon Ball", "JoJo's Bizarre Adventure" and other comics are the friends which grew up with us. In addition to the attractive plot, the wonderful picture painted by comic masters are also one of the important reasons that we choose the comic. Before computer is used in the field of painting, all the visual elements in comic were done by hand. The workload comic masters was quite big, therefore, the masters at that time needed one or several assistants to complete the other visual effects or background except the main characters. Now, thanks to the successful application of computers, cartoon creation becomes much simpler.

The net effect of the garments can be stored in computer in the form of material for use at any time. The process of stick net paper is not as difficult as before. The marquee tool or pen tool of photoshop can divide the range with few mistakes. If there are mistakes, the historical error recovery tool can recover the picture. Some software like ComicStudio is specially invented for producing comics. The tool bar in the software also include all paper effects needed in comics.

\section{THE REASON OF THE SUCCESSFUL COOPERATION BETWEEN COMPUTERS AND ILLUSTRATIONS}

\section{A. The advantage of computer technology}

Computer technology simplifies the illustration drawing tools and makes illustrators can relief from multifarious tool materials. Painters have to use paint and canvas; traditional Chinese painters have to use pen, ink, paper and inkstone; sculptors have to be involved in mud, stone and knife. It is impossible for any artist to make a good work without these tools. The application of computers make illustrations basically achieve paperless drawing process. It can draw the same great content without pen or ink.

\section{B. Digital illustration has strong social demand}

The public's aesthetic habits gradually tends to digital. Computer's success does not only lie in the communication of science and art, the more important is that it links up the tradition and the future of art creation and changes people's understanding of art. As is known to all, digital illustration has become more and more close to the public life. Digital illustration is widely used in school education, enterprises and institutions or business and other design related industries from all walks of life. By its own convenient, unique and abundant visual effects, etc., digital illustration brings people great joy. People in all walks of life have become the main part of art consumption, they gradually form the visual habit of 
digital products and gradually form a demand and expect for $\mathrm{CG}$ products.

\section{CONCLUSION}

The continuous development of computer hardware and software technology has injected new vitality for the illustration art and also provides convenient for the business demands of the constantly changing and developing market. To create illustrations by computers is an unprecedented change in ways of expression, creation and drawing speed, comparing to the traditional illustrations

Digital illustration art is a new art from which combines science and technology, painting, design, business and other factors. Along with the strengthening of commercial and the continuous development of computer hardware and software technology, digital illustration will render diversification trend in performance forms and the trend of multimedia application. Its functions will set up independent and dominant position gradually in addition to assist and foiling.

\section{REFERENCE}

[1] Davis, Fred D., R. P. Bagozzi, and P. R. Warshaw. "User Acceptance of Computer Technology: A Comparison of Two Theoretical Models." Management Science 35.8(1989):982-1003.

[2] Davis, Fred D., R. P. Bagozzi, and P. R. Warshaw. "User Acceptance of Computer Technology: A Comparison of Two Theoretical Models." Management Science 35.8(1989):982-1003.

[3] Wears R L, Berg M. Computer Technology and Clinical Work: Still Waiting for Godot[J]. Jama, 2005, 293(10):1261-1263.

[4] Venkatesh V, Speier C. Computer Technology Training in the Workplace: A Longitudinal Investigation of the Effect of Mood[J]. Organizational Behavior \& Human Decision Processes, 1999, 79(1):1-28.

[5] Ma W W, Robert A, Karl - Oskar S. Examining User Acceptance of Computer Technology: An Empirical Study of Student Teachers.[J]. Journal of Computer Assisted Learning, 2005, 21(6):387-395.

[6] Friedman, Batya. Human values and the design of computer technology. Center for the Study of Language and Information, 1997.

[7] Collins, Allan. "The Role of Computer Technology in Restructuring Schools.." Phi Delta Kappan 73.1(1991):28-36.

[8] Hasselbring, T. S., and C. H. Glaser. "Use of computer technology to help students with special needs.." Future of Children 10.2(2000):102-22.

[9] Lehmer, D. H. (1969). Computer technology applied to the theory of numbers. Studies in Number Theory.

[10] Chapelle, C., \& Douglas, D. (2006). Assessing language through computer technology. Cambridge University Press.

[11] Vigdor, J. L., Ladd, H. F., \& Erika, M. (2010). Scaling the digital divide: home computer technology and student achievement Social Science Electronic Publishing, 52(3), 1103-1119As the access to this document is restricted, you may want to look for a different version under "Related research" (further below) orfor a different version of it.

[12] Shields, M K, and R. E. Behrman. "Children and Computer Technology." Future of Children 10(2000). 